\title{
Hakusanoja työstä
}

Keijo Rahkonen

'Jos on jotakin, mitä marxilaisen filosofian pitäisi panna toimeen, se on: pyrkiä tarkastelemaan historiallisesti käsitteitä, joita käytetään historian tarkastelussa."

Pierre Bourdieu (Sosiologia 4/83)

HAKUSANOJA? Mitä se tarkoittaa? Pari sanaa selitykseksi. 'Hakusana' ei tässä tarkoita ensyklopedista tietoa, jota voidaan hakea tietosanakirjasta. Tässä yhteydessä 'hakusana' viittaa - paitsi avainsanaan - 'hakemiseen', 'etsimiseen', miksei myös 'hakuammuntaan'. Etsin siis 'työn' merkityksiä, eritoten Marxilta.

TYÖYHTEISKUNTA. Sekä klassisessa porvarillisessa että marxilaisessa traditiossa työ on keskeinen yhteiskunnallinen avainkategoria. Sen mukaan konstituoituu moderni, kapitalistinen yhteiskunta. Työyhteiskunta ei siis ole ylihistoriallinen käsite (vaikka molemmissa traditioissa esiintyy taipumusta projisoida työn sabloni sekä menneisyyteen että tulevaisuuteen). Toisin sanoen, modernille yhteiskunnalle on olennaista, että se organisoituu työn mukaan eli että työ on sen järjestysperiaate - ei vain taloudellisessa, vaan myös sosiaalisessa ja moraalisessa mielessä. Ranskalainen sosiologi Jean Baudrillard on luonnehtinut lennokkaasti mutta mielestäni hyvin työyhteiskuntaa ja sen kriisiä: "Työ (myös vapaa-ajan muodossa) koskettaa koko elämää, perustavanlaatuisena repressiona, kontrollina, jatkuvana toimintana määrätyillä paikoilla ja määrättyinä aikoina, kaikkialla läsnä olevan koodin mukaan. Ihmisen täytyy kiinnittyä kaikkialla, koulussa, tehtaassa, rannalla, television ääressä tai ammatillisessa jatkokoulutuksessa - jatkuvaan ja yleiseen mobilisaatioon. Tämä työ ei kuitenkaan ole enää alkuperäisessä mielessä tuottavaa: se on enää vain yhteiskunnan peili, sen imaginaarinen, sen mielikuvituksellinen todellisuusperiaate. Kenties sen kuolemanvietti."'
'Työyhteiskunnalla' tarkoitetaan siis tässä historiallisesti spesifiä yhteiskuntaa, kapitalistista yhteiskuntaa. Esikapitalistiset yhteiskunnat (vrt. feodalismi tai antiikki) tai yhteisöt ovat organisoituneet toisin - tämä kuuluu marxisminkin aapistotuuksiin.

TYÖN VAIKEA MÄÄRITTELY. Kysymykseen "Mitä on työ?" on tapana marxilaisissa piireissä vastata siteeramalla Marxin Pääoman I kirjaa: "Työ on lähinnä ihmisen ja luonnon välinen prosessi, jossa ihminen toiminnallaan (saks. Tat, teko, työ) välittää, ohjaa ja valvoo aineenvaihduntaa itsensä ja luonnon välillä."’ - Tämä määritelmä on yhtä tosi kuin triviaalikin siinä mielessä, että ihmisen (joka on myös osa luontoa) ja luonnon välillä lienee ollut vuorovaikutusta kautta (ihmis)aikojen. Tosin verbit "...välittää, ohjaa ja valvoo" on tällöin tulkittava ei-modernisti.

Kyseistä vuorovaikutusprosessia Marx kutsuu siis työksi. Olisi kuitenkin väärin tulkita tämä työn niin sanoakseni tekninen määritelmä spesifisti marxilaiseksi, so. kapitalismikriittiseksi. Tämä määritelmä ei olekaan Marxin keksintö, vaan yleisesti hyväksytty porvarillinen, ts. porvarillisen yhteiskunnan (itse)ymmärrys työstä. Se on porvarillisen aikakauden synnyttämä käsitys ihmisen ja luonnon suhteesta.

Itse asiassa Marx näyttää olevan tästä tietoinen. Grundrissessa hän kirjoittaa, että käsitys työstä "työnä yleensä on ikivanha. Kuitenkin, taloudellisesti näin yksinkertaisesti käsitettynä, 'työ' on yhtä moderni kategoria kuin ne suhteet, jotka tämän yksinkertaisen abstraktion luovat... Siis vasta tällöin 'työn' kategorian abstraktiosta, 'työstä yleensä', työstä sans phrase, modernin ekonomian lähtökohtana, tulee praktisesti tosi... Tämä esimerk-

1 Jean Baudrillard: Der symbolische Tausch und der Tod (München 1982), s. 28.

2. K. Marx: Pääoma I (Moskova 1974), s. 168; käännöstä korjattu, vrt. MEW 23, s. 193. 


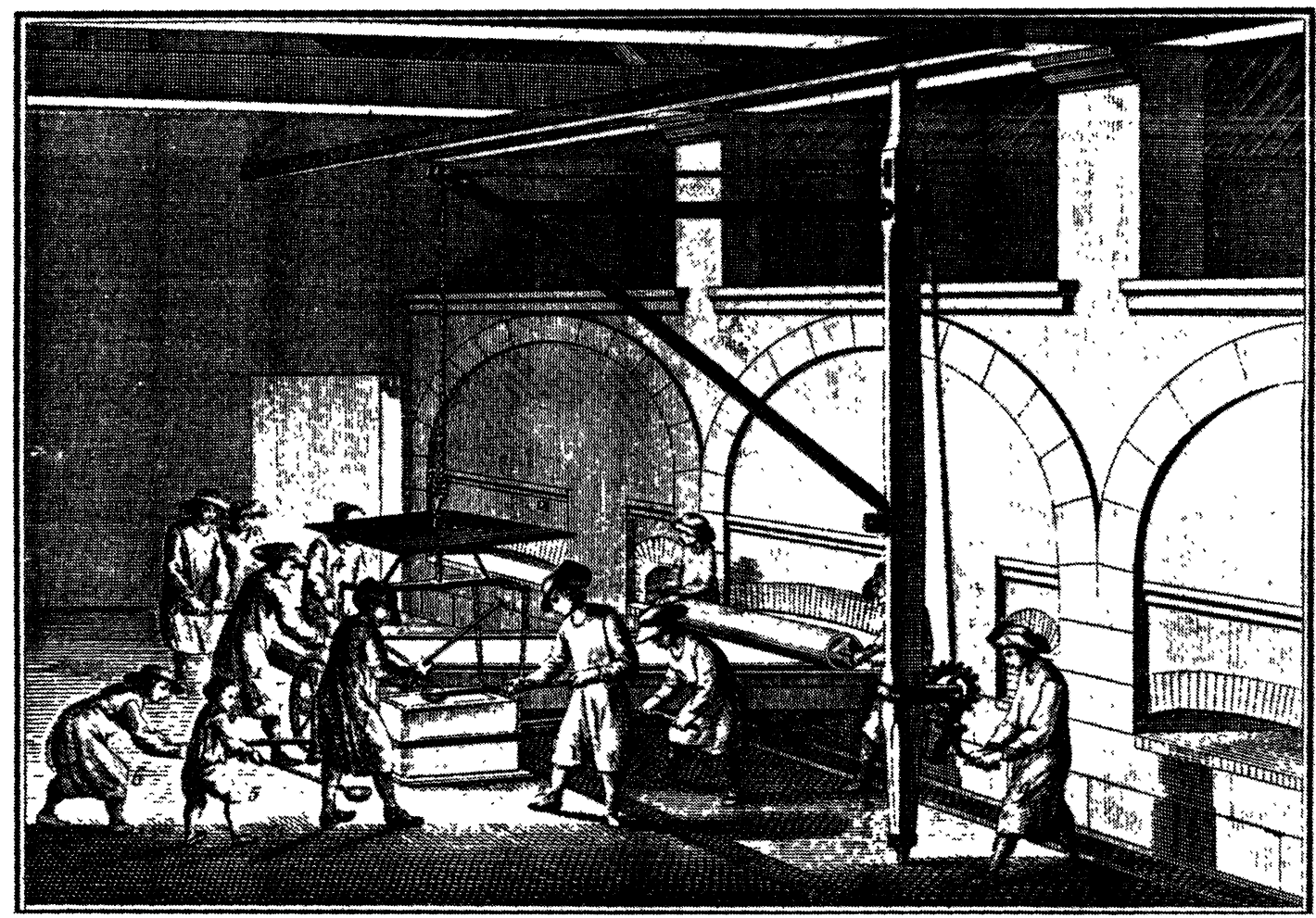

$\square$ Denis Diderot: L'encyclopedie ou Dictionaire Raisonné des Sciences, des Arts et des Metiers (1763) - Ideaalikuva lasinvalmistuksesta.

ki työstä osoittaa osuvasti, kuinka itse abstrakteimmat kategoriat, huolimatta niiden pätevyydestä... kaikkina aikakausina, kuitenkin ovat itse tämän abstraktin määrityksen suhteen yhtä paljon historiallisten suhteiden tuote ja saavuttavat täyden pätevyytensä vasta näihin suhteisiin nähden ja niiden piirissä."3

Minusta tämä Marxin argumentaatio on sisäisesti ristiriitainen. Marx näyttää yrittävän argumentoida toisaalta, että käsitys 'työstä yleensä' on ikivanha, toisaalta että kategoria 'työ yleensä' on moderni, historiallisten suhteiden tuote. Siis ikään kuin Idea 'työstä yleensä' olisi universaalihistoriallinen Ideana, mutta tulisi todeksi "praktisesti" vasta modernis-

3. K. Marx: Grundrisse (Berlin 1953), s. 24-25. sa, kapitalistisessa yhteiskunnassa. ${ }^{3 \mathrm{~b}}$

Marxin väite että käsitys 'työstä yleensä' olisi "ikivanha" on niin sanoakseni empiirisesti epätosi, esim. nykyisen antropologisen tie-

3 b Tähän Grundrissen kohtaan liittyy vanha, 70luvulla paljon puitu loogisen ja historiallisen suhde. Esitykseni ei ole - ainakaan suora kannanotto siihen. Sen sijaan tarkasteluni on eräässä mielessä analoginen käyttöarvon statusta koskevalle Marx-kritiikille (vrt. esim. J. Baudrillard: Le Miroir de la production, Paris 1973) sekä Marx-kriittisille arvioille työprosessin käytöstä normatiivisena mittapuuna; vrt. toisaalta Georg Lohmann: Gesellschaftskritik und normativer Masstab, teoksessa A. Honneth \& U. Jaeggi (hrsg.): Arbeit, Handlung, Normativität (Fr/M. 1980), toisaalta KlausDieter Oetzel: Wertabstraktion und Erfahrung (Fr/ M\&N.Y. 1978) ja Stefan Breuer: Die Krise der Revolutionstheorie (Fr/M 1977). 

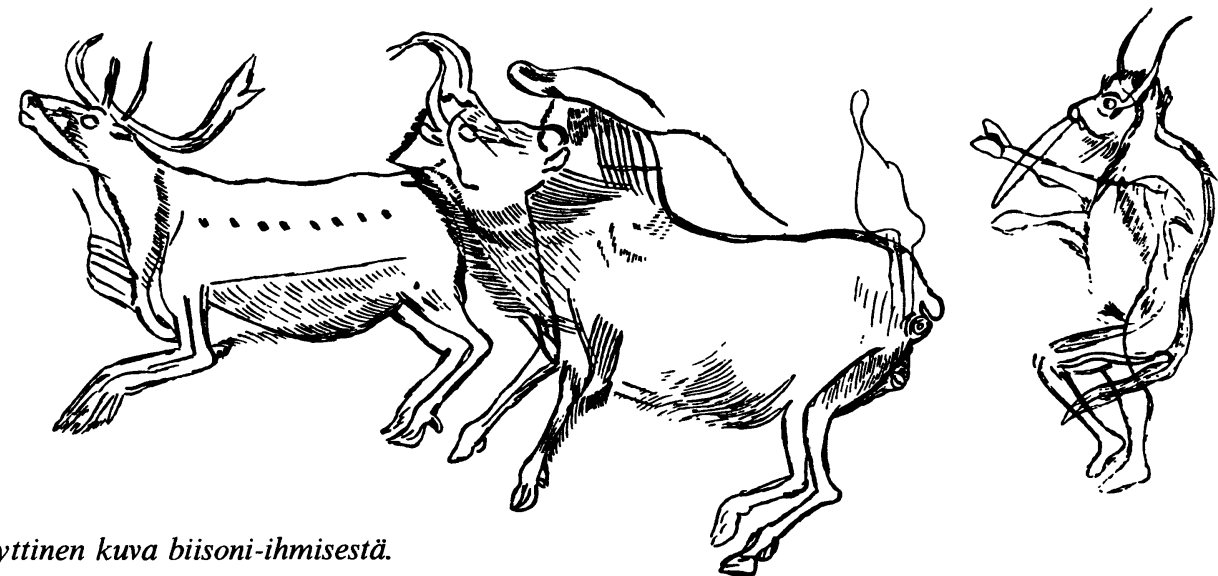

Myyttinen kuva biisoni-ihmisestä.

don valossa (ns. primitiivisillä heimoilla ja yhteisöillä ei esiinny mitään yleiskäsitettä sellaisille - nykyisin konkreettisiksi töiksi kutsutuille - toiminnoille kuten metsästys, kalastus etc.). Tätä vastaväitettä voi illustroida myös 'työn' etymologisella erittelyllä. ${ }^{4}$ Käsitys 'työstä yleensä' syntyy - kuten Marx aivan oikein toteaakin - vasta modernissa kapitalistisessa yhteiskunnassa abstraktin työn kategorian myötä, jonka käsitteen klassinen poliittinen taloustiede tematisoi käsitteellisesti. Marxin väitettä 'työn yleensä' "pätevyydestä... kaikkina aikakausina" voidaan tässä mielessä pitää paitsi ristiriitaisena (suhteessa kapitalismispesifiin abstraktin työn käsitteeseen) modernille työyhteiskunnalle tyypillisenä tapana tulkita historiaa. Toisin sanoen, Marxin käyttämä darwinistinen metafora "ihmisen anatomiassa on avain apinan anatomiaan"s on (ainakin) tältä kannalta reduktionistinen ja virheellinen.

Edellä esitetty on nähdäkseni osoitus siitä, että Marxin käsitys työstä on hänen ns. kypsässä tuotannossaankin ristiriitainen. Myös Marx on työyhteiskunnan vanki; hän ei vienyt poliittisen taloustieteen kritiikkiään riittävän

\footnotetext{
4. Ks. esim. yleisesityksenä Arne Helldén: Arbete. Ur arbetets idéhistoria (Södertälje 1979).

5 Grundrisse, s. 26.
}

pitkälle. Marxin esitys porvarillisesta yhteiskunnasta jäi keskeneräiseksi, puutteelliseksi. Ennen kaikkea tämä puutteellisuus heijastuu Marxin historiankäsityksessä ja kommunismin ennakoinneissa, joihin tulen tuonnempana.

TYÖ ANTROPOLOGISENA VAKIONA. Edellä lainatussa Pääoman I kirjan kohdassa Marx toteaa, että "me tarkoitamme työtä muodossa, joka on yksinomaan ihmiselle ominainen." Tätä käsitystä pidetään myös tyypillisesti "marxilaisena" ihmiskäsityksenä. Näin ei kuitenkaan ole. Marx omaksui tämän antropologisen - eikä vain sen - käsityksen Hegeliltä. En tarkoita tässä Marxin itse Pääomassa korostamaa trivialiteettia Hegelin "jaloilleen pyöräyttämisestä", vaan tämän tempun kyseenalaisuutta tai vähintäänkin puutteellisuutta.

Hegel käsitti työn taloudellisesti, antropologisesti ja historiallisesti ja kytki työn eräänä keskeisenä käsitteenä systeemiinsä. ${ }^{7}$ Taloudellisen käsityksen työstä Hegel omaksui Steuartilta ja Smithiltä, täydentäen sitä myöhemmin Sayllä ja Ricardolla. Mutta hän ei rajan-

6 Pääoma I, s. 168.

7 G.W.F. Hegel: Phänomenologie des Geistes (1807), erit. jaksot IVA, VIII Ac; Rechtsphilosophie (1821), § $182 \mathrm{ff}$. 
nut työtä pelkästään talouden alueelle. Hegelille 'työ' merkitsi vain ihmiselle ominaista tavoitteellista toimintaa tarpeiden tyydyttämiseksi. Samalla työ sai metafyysis-historiallisia piirteitä "Hengen tulemisessa" (Werden des Geistes) ja "vapauden toteutumisessa" maailmanhistoriallisessa prosessissa. ${ }^{8}$ Tiivistetysti: ihmisen työ vastasi Hegelin mukaan Maailmanhengen työtä, so. Jumalan tahtoa. Työn vapautumisessa Hegel näki ajan merkin. ${ }^{9}$

On sangen helppo osoittaa, että Marx on nuoruudentuotannossaan (esim. Taloudellisfilosofisissa käsikirjoituksissa) vahvasti Hegelin vaikutuksen alainen. Mutta tämä pätee Marxin historiankäsitykseen ylipäänsä. Esittäessään profaanin historian käsitteen Marx liittää juuri työn fundamentaaliseksi historiateoreettiseksi kategoriaksi transponoimalla Hegelin 'Hengen' käsitteen 'työn' käsitteeksi, joka liitetään ihmiseen lajispesifisenä, antropologisena kykynä (ja vakiona). Tällöin Marx pitää rakenteellisesti (subjekti - objekti -logiikka) kiinni Hegelin 'Hengen' käsitteestä. Marxin on siis epähistoriallistettava historiaa tuottava momentti: niin kuin Hegel operoi Hengellä jonakin, joka ennen kaikkea asettaa ja tuottaa historian, mutta jota itseään ei tuoteta historiassa, Marx esittää työn sellaisenaan historiaa liikuttavaksi voimaksi - esittämättä työn (logiikan) syntyä historiassa. Täten nuoren Marxin historiankäsitys saa universaalihistoriallisen analyysin intention - ja vastaavasti 'työ' universaalihistoriallisen pätevyyden. ${ }^{10}$

8 Manfred Riedel: Theorie und Praxis im Denken Hegels (Stuttgart\&Berlin 1965), s. 62.

9 Hegel: Phänomenologie des Geistes, jakso VII Ac.

10 Tämän on esittänyt jo H.-J. Schanz: Til rekonstruktionen af kritikken af den politiske økonomis omfangslogiske status (Aarhus 1973), s. 2037; Marxin erilaisista 'työn' käsitteistä ks. E. M. Lange: Das Prinzip Arbeit (Frankfurt/M. Berlin - Wien 1980).
Nuoren ja kypsän Marxin ajattelun välillä on tunnetusti "katkos", käänne nuoruudenkirjoitusten feuerbachilais-antropologistisesta subjekti - objekti -logiikasta ekonomiakriittiseen spesifisti yhteiskunnalliseen subjekti - objekti -logiikkaan (jossa subjekti on pääoma). Marx siis irtautuu pitkälle Hegelin vaikutuksesta, samoin kuin klassisen poliittisen taloustieteen vaikutuksesta esittäessään poliittisen taloustieteen kritiikin. Mutta eräässä olennaisessa kohdassa, nimittäin käsityksessään työstä, Marx ei pääse irti jo nuoruudenajatteluunsa sisältyneestä käsityksestä työstä antropologisena vakiona - ei ainakaan täysin, mitä mielestäni osoittaa edellä eritelty Grundrisse-passus. Eri asia on tietenkin lähinnä postmarxilaisessa kirjallisuudessa esitetty - ennen muuta Engelsiin nojautuva - historiankäsitys, jossa työ on ylivertainen ja ylihistoriallinen demiurgi, sanalla sanoen: eräänlainen profaani Maailmanhenki.

Marxin tuotannosta löytyy epäilemättä useita erilaisia ja keskenään ristiriitaisia käsityksiä työstä. Marxin ambivalenssi sallii moninaisia tulkintoja. En ole edellä käynyt läpi näitä sen paremmin kuin Marxinkaan käsityksiä systemaattisesti ja tyhjentävästi. Olen toisaalla $^{11}$ pyrkinyt osoittamaan, että moderni, nykyisin vallitseva käsitys työstä on historiallisesti spesifi. Sekä porvarillisessa että marxilaisessa perinteessä yleensä operoidaan kuitenkin - nolens volens - nykyisellä työn käsitteellä ikään kuin se olisi universaali (sekä historiallisesti että kulttuurisesti). Toisin sanoen sille annetaan tavallaan sama status kuin gravitaatiolaille tms. luonnontieteelliselle laille, joka on pätenyt ennen itse lain formulointia. Jos nykyinen työn tematisointi (mukaan lukien työn ns. tekninen määritelmä, joka jo

11 K. Rahkonen: Mitä?? "Tÿ̈." Ymmärtäköön tämän ken taitaa. (Helsinki 1983), s. 32ff. 
edellyttää abstraktin työn käsitettä) projisoidaan à la Hegel menneisyyteen ja tulevaisuuteen, joudutaan sellaiseen reduktionismiin, mistä Marshall Sahlins on kritisoinut (Saksalaisen ideologian) Marxia: "Historiallisen materialismin ehdoton pohjautuminen työhön ja työn sen aineellisiin erittelyihin riistää teorialta sen kulttuuriset ominaisuudet ja jättää sen saman kohtalon nojaan kuin antropologisen materialismin."”12

Mutta universaalihistoriallista käsitystä työtä vastaan voidaan esittää myös muita argumentteja. Vastaavasti kuin Sahlins on Michel Foucault esittänyt historiallisen muistutuksen marxilaisille - jotka kerskuvat historiallisella tietoisuudella. Foucault kirjoittaa: "On väärin sanoa, 'eräiden tunnettujen jälkihegeliläisten tavoin', että ihmisten konkreettinen eksistenssi on työ. Ihmisten elämä ja aika eivät ole luonnostaan työtä; ne ovat: iloa, rauhattomuutta, juhlaa, lepoa, tarvetta, sattumaa, haluamista, väkivaltaa, rosvoamista jne. Pääoman on muutettava koko tämä räjähtävä, silmänräpäyksellinen ja epäjatkumollinen energia jatkumolliseksi ja jatkuvasti markkinoilla olevaksi työvoimaksi. Pääoman täytyy syntetisoida elämä työvoimaan - ja se edellyttää pakkoa...."13

TYÖVÄENLIIKE JA 'TYÖN FILOSOFIA'. Marx oli siis aikansa lapsi - työyhteiskunnan ajattelun vanki. Mutta ei täysin. Marxilta nimittäin löytyy eräs varsin poikkeuksellinen visio työn tulevaisuudesta - visio, jota ei ole ennen kuin viime aikoina osattu oikeastaan edes etsiä. Tällä tarkoitan Marxin Pääoman käsikirjoituksissa esittämää kommunismin visiota "vapauden valtakunnasta" (Pääoman III kirja) ja erityisesti "vapaasta ajasta",

12 M. Sahlins: Culture and practical reason (Chicago\&London 1976), s. 134- 135.

13 M. Foucault: Die Macht und die Norm, teoksessa M. Foucalt: Mikrophysik der Macht (Berlin 1976), s. 102; KR:n kurs. jota hän käsitteli vain Grundrissessa (1857/ 58).

Sanoin, ettei sitä osattu etsiäkään. Tällä tarkoitan, että Marxin jälkeinen työväenliike loi viime vuosisadan lopulla - historiallisesti ymmärrettävistä syistä - identiteetilleen tarpeellisen "työn filosofian", joka kiinnittyi kritiikittömästi (ja tiedostamattomasti, muutamaa poikkeusta lukuunottamatta) vallinneeseen työn käsitteeseen. Mielestäni Walter Benjamin on tiivistänyt oivallisesti tämän käsityksen 11. historianfilosofisessa teesissään (jota en väsy lainaamasta). Benjamin huomauttaa mm. kuinka "protestanttinen etiikka juhli maallistuneessa hahmossa ylösnousemustaan saksalaisissa työläisissä". ${ }^{14}$ Benjamin viittaa Saksan vanhan sosialidemokraattisen puolueen Gothan ohjelmaan, joka sisälsi mahtipontisen työn ylistyksen "kaiken rikkauden ja kulttuurin lähteenä". Marx ei tunnetusti hyväksynyt tätä käsitystä (huomauttaen että luontohan se on yhtä hyvin kaiken rikkauden lähde). Mutta Gothan ohjelman kritiikissä hän esittää kommunismista puhuessaan varsin ambivalentin formuloinnin siitä, kuinka kommunismissa työstä tulee "ensimmäinen elämäntarve". ${ }^{15}$

Tässä Marxin formuloinnissa elämä redusoituu tavallaan työksi lopullisesti. Eli kommunismi vie tavallaan loppuun kapitalistisen työyhteiskunnan kehityksen, jolloin pääoma "syntetisoi elämän työvoimaan", kuten Foucault esitti. Pulmallinen on myös tällöin Marxin pohjalta kehitelty käsitys kommunismista "vapaiden ja tietoisten uurastajien pitkälle organisoituneena yhteiskuntana,... jossa työ $y h$ -

14 W. Benjamin: Geschichtsphilosophische Thesen, teoksessa W. Benjamin: Illuminationen. Ausgewählte Schriften 1 (Frankfurt/M 1961), s. 274.

15 K. Marx: Gothan ohjelman arvostelua. Marx/ Engels: Valitut teokset, 5. osa (Moskova 1979), s. 538 . 


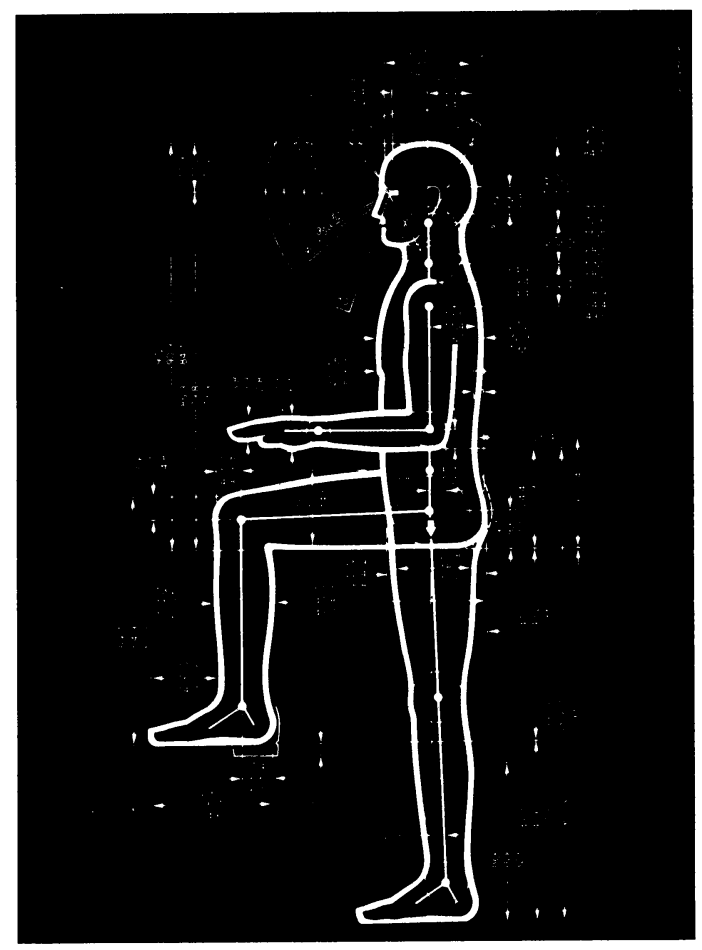

$\square$ Abstrakti työ - mitattuja liikkeitä.

teiskunnan hyväksi muuttuu kaikkien ensimmäiseksi elämäntarpeeksi". ${ }^{16}$ Tämän käsityksen mukaan työ muuttuu kommunismissa "todella vapaaksi" ja "vapaaehtoiseksi asiaksi, yhteiskunnan kaikkien jäsenten sisäiseksi tarpeeksi." ${ }^{17}$

Edellä lainattu käsitys on monessakin mielessä pulmallinen, mutta en ryhdy tässä tarkemmin erittelemään sitä. Haluan vain todeta, että tällainen työhön kiinnittyminen ilman kriittistä käsitehistoriallista analyysia ja ns. utooppisen työn käsitteen eksplikointia kommunismiin siirretään sellaisia työyhteiskunnan elementtejä, jotka merkitsevät pikemmin-

16 NKP:n ohjelma, sit. B. Ponomarjov: Ihmiskunnan tulevaisuuden näköalat marxilaisten näkökulmasta (Sosialismin teoria ja käytäntö 2/ 1984), s. 5; KR:n kurs.

17 Ponomarjov, s. 7; KR:n kurs. kin kapitalistisen työyhteiskunnan täydellistymistä kuin sen lakkauttamista. Tässä konseptiossa myös vapaa-aika jää kommunismissa edelleen vapaa-ajaksi perinteisessä mielessä, ${ }^{18}$ eikä se saa samaa statusta ja merkitystä kuin Marxilla.

VAPAAN AJAN käsite onkin mielestäni se Marxin käsite, jonka pohjalta ainoastaan voidaan tematisoida ja ennakoida kommunismin utopiaa. Tämän utopian Marx hahmottelee vain kerran vieläpä varsin suppeasti Grundrisse-käsikirjoituksessa. Grundrissessa Marx katsoo, että juuri vapaa aika (ei nykyisessä työlle alisteisessa vapaa-ajan merkityksessä) merkitsee "yksilön täyden kehittymisen aikaa", joka "puolestaan suurimpana tuotantovoimana vaikuttaa takaisin työn tuotantovoimaan". ${ }^{19}$ Marx ei siis tässä pidä työtä yksilön (huom. Marx tarkastelee kommunismia oleellisesti yksilön kehityksen kannalta) kehityksen kannalta ensisijaisena. Päinvastoin, hänen mukaansa juuri "vapaa aika... muuttaa... sen, jolla sitä on käytettävissään, toiseksi subjektiksi, ja hän astuu tänä toisena subjektina myös välittömään tuotantoprosessiin." ${ }^{20}$

Vastaavasti Marx korostaa vapaan ajan merkitystä Pääoman III kirjan tunnetussa jaksossa vapauden ja välttämättömyyden valtakunnasta. Marxin mukaan kommunismin kehityksen "perusedellytys on työpäivän lyhentäminen". ${ }^{21}$ Nähdäkseni nämä Marxin lausunnot ovat ristiriidassa hänen Gothan ohjelman kritiikissä esittämänsä kannan kanssa, jonka mukaan kommunismissa työstä tulisi "ensimmäinen elämäntarve". Muuten Marx ei kai pitäisi kommunismin "perusedellytyksenä" nimenomaan työajan lyhentämistä - vaan pikemminkin pidentämistä, jolloin elämä ikään kuin täyttyisi työstä (millaista se sitten kvali-

18 ib., s. 8.

19 Grundrisse, s. 599; KR:n kurs.

$20 \mathrm{ib}$.

21 Pääoma III(Moskova 1976), s. 808; KR:n kurs. 
tatiivisesti olisikaan), mikä merkitsisi "rikkaan yksilöllisyyden" kehityksen deformoitumista 'työ-yksilöllisyydeksi'.'

Sanottakoon tässä yhteydessä, että en väitä, että edellä puolustamani Marxin "vapaan ajan" visio olisi päiväjärjestyksessä sellaisenaan. Marx asettaa itse tälle vahvoja ehtoja, joista tärkein on rikkauden muoto. Työaika lakkaisi tällöin olemasta rikkauden mitta. Uudeksi rikkauden muodoksi (so. kvalitatiiviseksi 'mitaksi') tulisi vapaa, disponiibeli aika. ${ }^{22}$

Väitän kuitenkin, että työyhteiskunnan kriisi - yleisemmin "the great civilizing influence of capital" - on tehnyt paradoksaalisesti ajankohtaiseksi Marxin vision. (Pessimistiset kulttuurikriitikot tosin väittävät, että kapitalismin kehitys, mm. kulttuuriteollisuus on osoittanut Marxin vapaan ajan visionkin virheelliseksi, mikä on varteenotettava argumentti, johon en tässä yhteydessä voi ottaa kantaa.)

TYÖYHTEISKUNNAN KRIISIÄ on diagnostisoitu ennen kaikkea sosiologian piirissä. ${ }^{23}$ Mitään systemaattista analyysia kriisistä ei ainakaan toistaiseksi ole esitetty, mutta yleensä kriisiä on luonnehdittu $\mathrm{mm}$. seuraavilla piirteillä: Tuotannon tasolla kuollut työ (automaatio) syrjäyttää yhä kasvavassa määrin elävää työtä, ihmistyövoimaa, mikä nykyisin näyttäytyy ns. teknologisena työttömyytenä. Vastaavasti työprosessi on muuttunut: työ ei enää välttämättä merkitse työntekijän ja työnesineen välitöntä kohtaamista. Työn tuotteet eivät enää ole monesti työntekijän välittömän ja suvereenin toiminnan tulosta (on puhuttu myös ammattien häviämisestä). Edelleen työn osuus ihmiselämässä (vrt. työajan ly-

22 Ks. Grundrisse, s. 386-7, 592-600.

$23 \mathrm{Ks}$. J. Matthes (hg.): Krise der Arbeitsgesellschaft. Verhandlungen des 21. Deutschen Soziologentages in Bamberg 1982 (Frankfurt\&New York 1982); A. Gorz: Les chemins du Paradis (Paris 1983), s. 73f. heneminen) on supistunut drastisesti tällä vuosisadalla. Lisäksi työn ja toimeentulon välinen riippuvuus on vähentynyt tai jopa hävinnyt. Piilevä ja vapaaehtoinen työttömyys on kasvanut. Näiden tekijöiden yhteisvaikutuksena on ennakoitu perinteisen työetiikan eroosiota ja puhuttu ns. jälkimaterialististen arvojen "hiljaisesta vallankumouksesta".

Kuten sanottu, edellä esitetyt piirteet eivät ole systemaattinen esitys ns. työyhteiskunnan kriisistä. Kyse on sangen sekalaisista ja eritasoisista tekijöistä, joiden yhteinen nimittäjä on työn merkityksen väheneminen. Tässä yhteydessä mielestäni tärkein on ensiksi mainittu, itse asiassa jo Marxin ennakoima työn tuotantovoiman kehitys. Tähän kapitalismin tendenssiin on tarttunut ennen muuta paljon parjattu André Gorz, joka on myös nostanut esiin painokkaasti välttämättömyyden ja vapauden valtakunnan erottelun merkityksen konkreettisena utopiana. ${ }^{24}$ Ernst Bloch on luonnehtinut konkreettista utopiaa ykseyden saavuttamisena lähi- ja kaukotavoitteiden välillä. ${ }^{25}$ Mielestäni juuri mikroprosessoriteknologian ja automaation kehityksen avaama näköala tarjoaa tietyn konkreettisen, kommunismia ennakoivan utopian, joka konkretisoituu ajankohtaisessa työajan lyhentämisen vaatimuksessa. Tätä on Gorz hahmotellut uusimmassa "paratiisin teitä" etsivässä kirjassaan: "Sellaisen elämän sijaan, joka on täysin alistettu tylsistyttävän työn jokapäiväiselle pakolle ja rasitukselle, automaatio voi avata mahdollisuu-

24 Ks. A. Gorz: Eläköön työttömyys (Helsinki 1982) ja Les chemins du Paradis (Paris 1983); teoreettisesti ja sanoisinko marxologisesti tarkemmin näitä Marxin ajatuksia on eritellyt $H$.J. Schanz: Traek af behovsproblematikkens idehistorie med saerlig henblik på Marx og Engels (Aarhus 1981), s. 295ff.

25 E. Bloch: Antizipierte Realität - Wie geschieht und was leistet utopisches Denken, teoksessa E. Bloch: Abschied von der Utopie? Vorträge. (Frankfurt/M 1980). 
den sellaiseen työhön, joka kestoltaan lyhennettynä voisi olla eräs rikkaamman elämän ulottuvuus, eikä välttämättä tärkein."’26

Gorz ei kuitenkaan tarkoita, että meidän tulisi alistua ilman muuta "vieraantuneeseen, köyhtyneeseen ja ikävystyttävään työhön," vaan sitä että meidän on tunnustettava, että valtaosalle palkkatyöläisiä työ on tällä hetkellä sellaista. Sitä on toki muutettava, Gorz sanoo, mutta tämä muutos, "joka on ollut työväenliikkeen kehittyneimmän osan päätavoite jo kaksikymmentä vuotta ei ole toteutumassa lähiaikoina eikä vastaavasti muodosta tällä hetkellä itsessään liikkeellepanevaa tavoitetta". Sen sijaan Gorz katsoo että "vieraantuneen työn paikan ja ajan supistaminen elämässämme on meidän ulottuvillamme, mikä tavoite voi olla liikkeellepaneva ja vapauttava, ja tähän päämäärään kohdistuva kollektiivinen pohdiskelu ja toiminta voi tehdä mahdolliseksi työn ehtojen, sisällön ja luonteen perustavanlaatuisen uudelleenmäärittelyn."27

TYÖN IMPLOOSIO. Jos edellä esitetyt arviot työyhteiskunnan kriisistä pitävät paikkansa, edessämme voi olla "työn imploosio", kasaanpainuminen, kuten Claus Offe on sanonut. ${ }^{28}$ Tämä edellyttää sellaista teoriaa, joka kykenee selittämään, miten työn ja tuotannon sfääri menettää yhteiskuntaa strukturoivaa ja organisoivaa merkitystään ja minkälaisia seurauksia sen sosiaalisen determinaatiovoiman menetyksellä on, esimerkiksi tämän prosessin vapauttaessa uusia toiminta-alueita sekä toimintoja ja rationaliteetteja. Tällaista teoriaa ei nähdäkseni ole marxilaisen tradition piirissä tällä hetkellä - eikä tulekaan, ellei työn kategorian statusta arvioida uudelleen marxilaisessa teoriassa.

26 A. Gorz: Les Chemins du Paradis, s. 193.

$27 \mathrm{ib}$.

$28 \mathrm{Cl}$. Offe: Arbeit als soziologische Schlüsselkategorie? Teoksessa J. Matthes (hg.): Krise der Arbeitsgesellschaft..., s. 59-60.
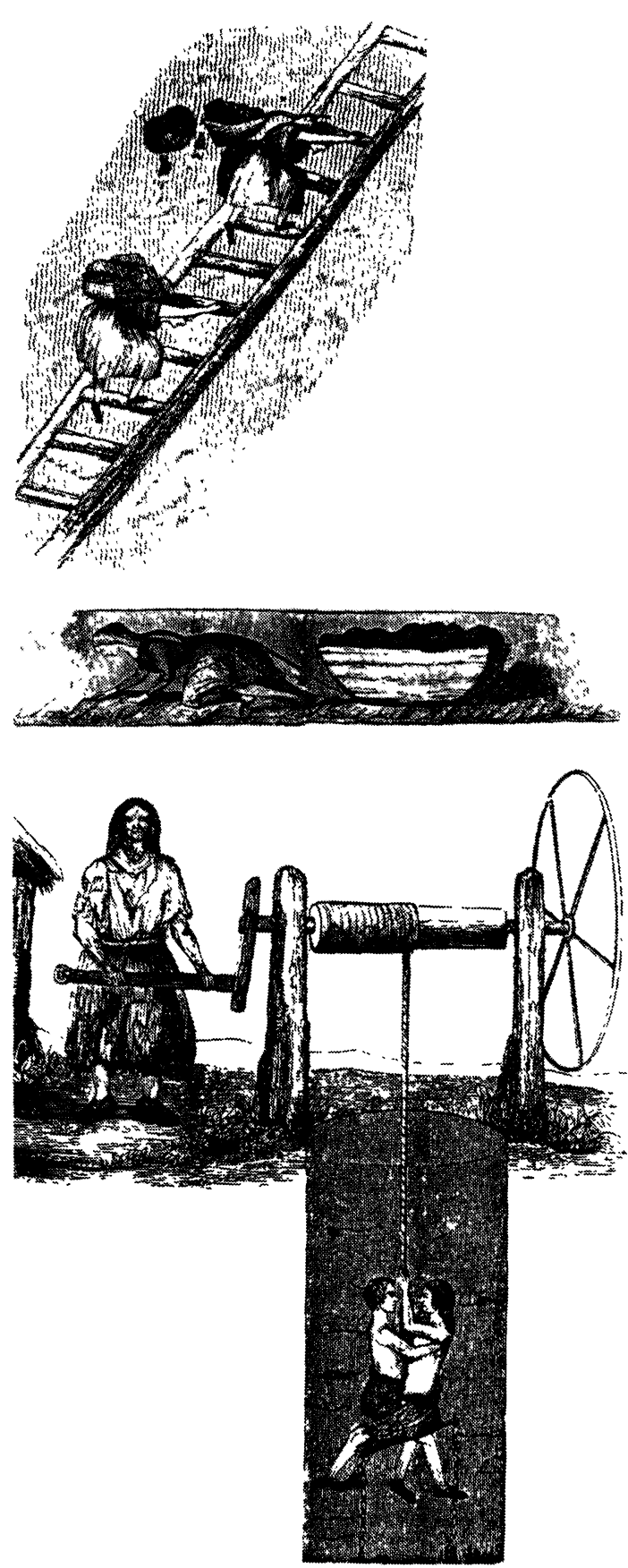

Lasten toimintaa englantilaisissa kaivoksissa, (Leipziger) Illustrierte Zeitung (1844). 